\title{
Mixed Infection of Sugarcane Yellow Leaf Virus and Grassy Shoot Phytoplasma in Yellow Leaf Affected Indian Sugarcane Cultivars
}

\author{
Kadirvel Nithya ${ }^{1}$, Balasubramaniam Parameswari ${ }^{2}$, and Rasappa Viswanathan ${ }^{1 *}$ \\ ${ }^{1}$ ICAR-Sugarcane Breeding Institute, Coimbatore 641 007, Tamil Nadu, India \\ ${ }^{2} I C A R$-Sugarcane Breeding Institute, Regional Centre, Karnal 132 001, Haryana, India
}

(Received on June 3, 2020; Revised on June 17, 2020; Accepted on June 25, 2020)

Sugarcane is an important sugar crop contributes more than $80 \%$ of world sugar production. Mosaic, leaf fleck, and yellow leaf (YL) are the major viral diseases affecting sugarcane, amongst $\mathrm{YL}$ occurrence is widely reported in all the sugarcane growing countries. It is caused by Sugarcane yellow leaf virus (SCYLV) and detailed works were done on complete genome characterization, transmission, and management. However, in countries like Egypt, South Africa, Cuba, Mauritius and Hawaii, the disease was reported to the cause of sugarcane yellow leaf phytoplasma (SCYP) and/or SCYLV as single/combined infections. Hence, we have investigated in detail to identify the exact Candidatus phytoplasma taxon associated in Indian cultivars affected with YL. The sequencing results and the restriction fragment length polymorphism pattern of the PCR products using the universal phytoplasma primers confirmed presence of sugarcane grassy shoot (SCGS) phytoplasma (16SrXI group) in the YL-affected plants. Mixed infection of SCYLV and SCGS phytoplasma was estimated as $32.8 \%$ in YL affected plants. Evolutionary genetic relationship between SCYP and SCGS phytoplasma representatively taken from different countries showed that SCYP from South Africa and Cuba were diverged from others and had a highest similarity with SCGS phytoplasma. Although we wanted to identify SCYP from YL affected Indian sugarcane cultivars, the

\section{*Corresponding author}

Phone) +91-422-2472621, FAX) +91-422-2473971

E-mail) rasaviswanathan@yahoo.co.in

(c) This is an Open Access article distributed under the terms of the Creative Commons Attribution Non-Commercial License (http:// creativecommons.org/licenses/by-nc/4.0) which permits unrestricted noncommercial use, distribution, and reproduction in any medium, provided the original work is properly cited.

Articles can be freely viewed online at www.ppjonline.org. study clearly indicated a clear absence of SCYP in YL affected plants and we found SCYLV as the primary cause for the disease.

Keywords : nested PCR, phylogeny, restriction fragment length polymorphism, sugarcane grassy shoot phytoplasma, Sugarcane yellow leaf virus

Handling Editor : Young-Su Seo

Sugarcane is one of the most important commercial crops grown mainly for sugar in many countries and also for bio energy production from its by-products such as, bagasse and molasses. It is being affected by several biotic factors like fungi, bacteria, viruses and phytoplasma causing reduction in production and productivity according to its severity. Among the viral diseases affecting sugarcane, yellow leaf (YL) (showing yellowing of midrib and lamina and in severe cases drying of entire leaf canopy) occurrence is reported in most of the sugarcane growing countries sometimes with up to cent percent incidence (Lehrer et al., 2008; Rassaby et al., 2004; Viswanathan, 2016). In 1960s, it was suspected to occur from East Africa and authentic reports of the disease had come from Hawaii in 1980s (Schenck 1990) followed by South Africa (Cronje et al., 1998) and Cuba (Arocha et al., 1999) and now distributed in all the sugarcane-growing countries causing losses up to $60 \%$ in susceptible varieties (Arocha et al., 2000; Comstock et al., 1998). In India, it was first reported during the year 1999 (Viswanathan, 2002; Viswanathan et al., 1999) since then its occurrence and severity continued in all the varieties (Viswanathan et al., 2006). The causative Sugarcane yellow leaf virus (SCYLV) belonging to Polerovirus; family Luteoviridae was reported in Hawaii, Brazil, Florida, and Australia whereas only phytoplasma association was reported from South Africa and Cuba and named as Sugar- 
cane yellow leaf phytoplasma (SCYP) (Arocha et al., 1999; Cronje et al., 1998). However, detection of both SCYLV and SCYP was reported in YL plants from Mauritius (Aljanabi et al., 2001; Parmessur et al., 2002) with suggestion of both were increasing the disease severity.

In India, SCYLV was identified as a causative agent of the disease (Rao et al., 2000; Viswanathan, 2002) through double antibody sandwich enzyme-linked immunosorbent assay (Gaur et al. 2003; Viswanathan and Balamuralikrishnan, 2004), reverse transcription PCR (RT-PCR) (Viswanathan et al., 2008, 2009). Subsequently detailed studies on disease epidemiology, aphid vector transmission, its impact on cane growth, yield and physiological parameters (Chinnaraja and Viswanathan, 2015a, 2015b; Viswanathan et al., 2008, 2014), complete genome characterization of the virus (Chinnaraja et al., 2013), real-time quantitative PCR assays to quantify virus titre in asymptomatic, symptomatic, and tissue culture derived plants (Chinnaraja et al., 2014) and tissue culture nurseries to manage the disease epidemics have been done effectively (Viswanathan, 2016; Viswanathan et al., 2018). Other than SCYLV, the phytoplasma disease, grassy shoot caused by sugarcane grassy shoot (SCGS) phytoplasma belonging to Rice Yellow Dwarf group or $16 \mathrm{SrXI}$ is also a major production constraint in sugarcane cultivation and reported to cause $5 \%$ to $70 \%$ yield reduction in plant crop and up to $100 \%$ in ratoon crops (Rao et al., 2012, 2014, 2017; Viswanathan, 2000; Viswanathan and Rao, 2011; Viswanathan et al., 2011). In severe cases, it totally affects the millable cane production and the affected clump produces only chlorotic thin tillers in numerous numbers which gives the typical grassy appearance. By this, the economically important cane stalks are lost, leading to heavy losses in cane yield under field conditions.
The SCGS disease causing phytoplasma is a small, oval to spherical shaped, obligate, endophytic, cell wall-less intracellular parasites resides in the phloem sieve tube and nearby companion cells, and vascular bundles of the host with 0.816-1.603 $\mu \mathrm{m}$ diameter in size (Nithya, unpublished) and have very small genome size of $505.17 \mathrm{~kb}$ (Kirdat et al., 2020). They are capable of invading and replicating in both plant and insect hosts. In plants, they inhabit in the nutrient-rich phloem tissues and spread systemically through sieve pores and induce various symptoms such as chlorotic leaves, stunting, and proliferation of axillary shoots, etc. due to abnormal endogenous phytohormone signaling (Bertaccini et al., 2014). In India, sugarcane is widely cultivated in $\sim 5.2 \mathrm{M}$ ha in varying climatic conditions and YL has been distributed throughout the country. Although SCYLV has been found in all the states, association of SCYP is not known except the report of Gaur et al. (2008) and Kumar et al. (2015) from subtropical India. Hence, an attempt was made to investigate the presence of SCYP in YL affected sugarcane cultivars from different geographical locations in India. Our studies clearly proved that SCYLV is the primary cause of YL disease in sugarcane cultivars and no SCYP association was found in any of the YL-affected plants, whereas some of the SCYLV infected plants had SCGS phytoplasma infection.

\section{Materials and Methods}

Sample collection. During the year 2016-2018, sugarcane leaves showing YL symptoms with severity grades of 3-4 with intense yellowing of leaf mid rib spread along the lamina region and severe drying of leaf from tip to downwards (Viswanathan et al., 2016) (Fig. 1A and B) were collected from Plant Pathology Farm, ICAR-Sugarcane
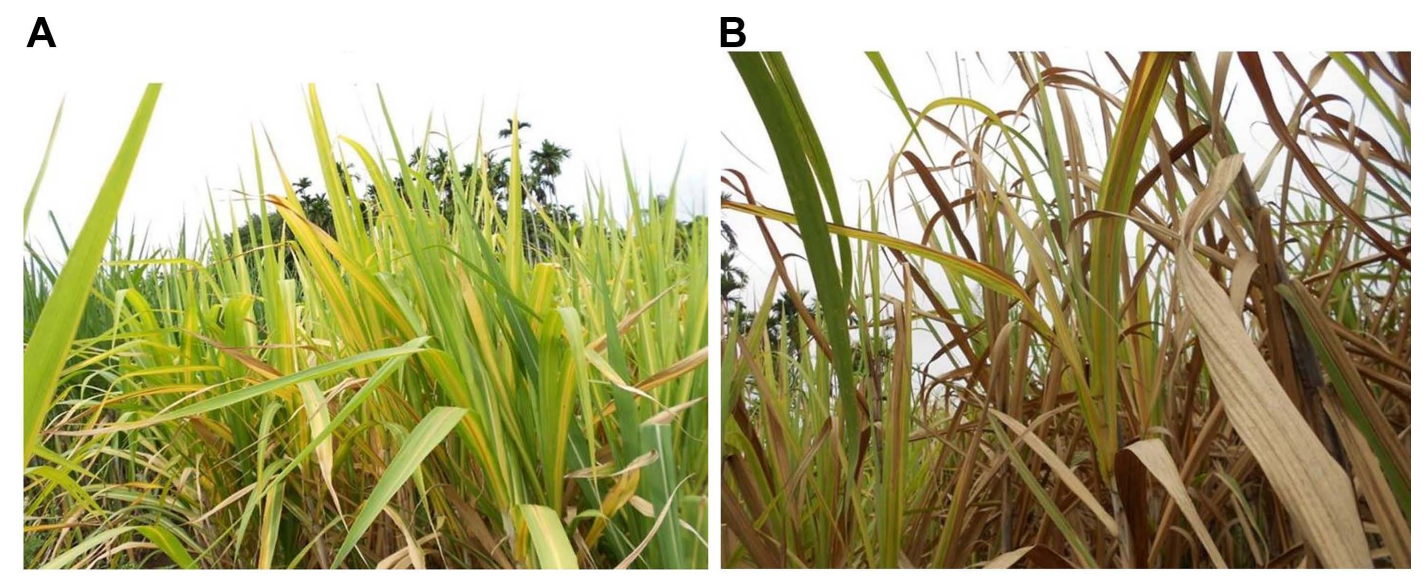

Fig. 1. (A) Severe expression of yellow leaf symptoms on sugarcane. All the leaves in the canopy express yellowing of mid rib and adjoin laminar region. (B) Severe expression of yellow leaf leads to extensive drying of foliage during harvest. 
Breeding Institute (ICAR-SBI) Coimbatore, and at ICARSBI regional Centre, Agali, Kerala and stored at $-80^{\circ} \mathrm{C}$ deep freezer until further processing. Amongst, the cv. Co 10031 in advanced varietal trial was strongly suspected for phytoplasma association as it had YL symptoms with severity grade of 4 along with stunting compared to other
YL plants. All the leaves, roots and different internode (3rd, 6th, and 9th) samples were taken for the diagnosis. The sample collection details were given in Table 1 .

RNA extraction and RT-PCR for SCYLV diagnosis. Total RNA was extracted from the collected leaf samples,

Table 1. Reaction of YL-suspected sugarcane varieties to SCYLV, SCGS phytoplasma in RT-PCR and nested PCR assays

\begin{tabular}{|c|c|c|c|c|c|}
\hline No. & Cultivar & Origin of the genotype/variety & SCYLV & $\begin{array}{c}\text { SCGS } \\
\text { phytoplasma }\end{array}$ & $\begin{array}{l}\text { Positive to both universal and } \\
\text { custom designed phytoplasma } \\
\text { primers }\end{array}$ \\
\hline 1 & 57 NG 56 & Coimbatore ${ }^{a}$ & + & + & - \\
\hline 2 & В 38192 & Coimbatore $^{a}$ & + & - & - \\
\hline 3 & Co 86010 & Coimbatore & + & + & + \\
\hline 4 & Co 86032 & Coimbatore & + & - & - \\
\hline 5 & Co 87269 & Coimbatore & + & + & + \\
\hline 6 & Co 99004 & Coimbatore & + & - & - \\
\hline 7 & Co 10031 & Coimbatore & + & + & + \\
\hline 8 & Co 11015 & Coimbatore & + & - & - \\
\hline 9 & CoC 671 & Cuddalore, Tamil Nadu & + & + & + \\
\hline 10 & $\operatorname{CoS} 767$ & Shahjahanpur, Uttar Pradesh & + & + & + \\
\hline 11 & $\mathrm{CoB} \ln 96009$ & Buralikson, Assam & + & - & - \\
\hline 12 & CoPant 94211 & Pantnagar, Uttarakhand & + & + & - \\
\hline 13 & $\operatorname{CoS} 767$ & Shahjahanpur, Uttar Pradesh & + & + & + \\
\hline 14 & CoT 8201 & Tirupathi, Andhra Pradesh & + & + & - \\
\hline 15 & PI 11131 & EID Parry, Pugalur & + & - & - \\
\hline 16 & BO 78 & Pusa, Bihar & + & - & - \\
\hline 17 & Co 449 & Coimbatore & + & + & + \\
\hline 18 & Co 740 & Coimbatore & + & - & - \\
\hline 19 & Co 875 & Coimbatore & - & - & - \\
\hline 20 & Co 1169 & Coimbatore & - & - & - \\
\hline 21 & Co 6304 & Coimbatore & + & + & - \\
\hline 22 & Co 8213 & Coimbatore & - & - & - \\
\hline 23 & Co 8342 & Coimbatore & + & - & - \\
\hline 24 & Co 85004 & Coimbatore & - & - & - \\
\hline 25 & Co 89003 & Coimbatore & - & - & - \\
\hline 26 & Co 94008 & Coimbatore & + & - & - \\
\hline 27 & Co 95007 & Coimbatore & + & - & - \\
\hline 28 & Co 88015 & Coimbatore & - & - & - \\
\hline 29 & Co 06027 & Coimbatore & + & - & - \\
\hline 30 & Co 06030 & Coimbatore & + & - & - \\
\hline 31 & Co 09014 & Coimbatore & - & - & - \\
\hline 32 & Co 09021 & Coimbatore & + & - & - \\
\hline 33 & Co 11001 & Coimbatore & - & - & - \\
\hline 34 & Co 11015 & Coimbatore & + & - & - \\
\hline 35 & Co 13015 & Coimbatore & - & - & - \\
\hline 36 & Co 85004 & Coimbatore & + & - & - \\
\hline 37 & CoA 8401 & Anakapalle, Andhra Pradesh & + & - & - \\
\hline 38 & CoA 89081 & Anakapalle, Andhra Pradesh & + & - & - \\
\hline
\end{tabular}


Table 1. Continued

\begin{tabular}{|c|c|c|c|c|c|}
\hline No. & Cultivar & Origin of the genotype/variety & SCYLV & $\begin{array}{c}\text { SCGS } \\
\text { phytoplasma }\end{array}$ & $\begin{array}{c}\text { Positive to both universal and } \\
\text { custom designed phytoplasma } \\
\text { primers }\end{array}$ \\
\hline 39 & CoA 89082 & Anakapalle, Andhra Pradesh & + & + & - \\
\hline 40 & CoA $90081(1)$ & Anakapalle, Andhra Pradesh & + & - & - \\
\hline 41 & CoA $90081(2)$ & Anakapalle, Andhra Pradesh & + & - & - \\
\hline 42 & CoA 92082 & Anakapalle, Andhra Pradesh & - & - & - \\
\hline 43 & CoA 01082 & Anakapalle, Andhra Pradesh & - & - & - \\
\hline 44 & CoBln 9006 & Buralikson, Assam & + & - & - \\
\hline 45 & $\mathrm{CoB} \ln 9101$ & Buralikson, Assam & + & - & - \\
\hline 46 & CoBln 9104 & Buralikson, Assam & + & - & - \\
\hline 47 & CoC 779 & Cuddalore, TamilNadu & + & - & - \\
\hline 48 & CoC 99061 & Cuddalore, TamilNadu & + & + & + \\
\hline 49 & CoC 01061 & Cuddalore, TamilNadu & + & + & + \\
\hline 50 & CoG 93076 & Gudiyattam, Tamil Nadu & - & - & - \\
\hline 51 & CoLk 8002 & Lucknow, Uttar Pradesh & + & + & + \\
\hline 52 & CoM 7712 & Padegaon, Maharashtra & - & - & - \\
\hline 53 & CoPant 84214 & Pantnagar, Uttarakhand & - & - & - \\
\hline 54 & $\operatorname{CoS} 8342$ & Shahjahanpur, Uttar Pradesh & + & - & - \\
\hline 55 & $\operatorname{CoS} 8436$ & Shahjahanpur, Uttar Pradesh & + & + & + \\
\hline 56 & CoSe 92423 & Seorahi, Uttar Pradesh & + & - & - \\
\hline 57 & CoSnk 03754 & Sankeswar, Karnataka & + & - & - \\
\hline 58 & CoSi 86071 & Sirugamani, TamilNadu & + & + & + \\
\hline 59 & CoV 89101 & Vuyyuru, Andhra Pradesh & + & + & + \\
\hline 60 & CoV 92101 & Vuyyuru, Andhra Pradesh & + & + & + \\
\hline 61 & CoV 92102 & Vuyyuru, Andhra Pradesh & + & + & - \\
\hline 62 & CoV 94101 & Vuyyuru, Andhra Pradesh & + & + & + \\
\hline 63 & $51 \mathrm{NG} 156$ & Coimbatore $^{\mathrm{a}}$ & - & - & - \\
\hline 64 & $57 \mathrm{NG} 77$ & Coimbatore $^{a}$ & - & - & - \\
\hline
\end{tabular}

YL, yellow leaf; SCYLV, Sugarcane yellow leaf virus; SCGS, sugarcane grassy shoot; RT-PCR, reverse transcription PCR.

${ }^{a}$ Coimbatore: Germplasm material.

ground in liquid nitrogen and resuspended with $1 \mu \mathrm{l}$ TRI reagent (Sigma, St. Louis, MO, USA) by following the manufacturer's protocol. The pellet was dissolved in a final volume of $30 \mu \mathrm{l}$ RNase free water and stored at $-80^{\circ} \mathrm{C}$. It was treated with DNase I (1 U/ $\mu$ l) (Thermo Fischer Scientific, Waltham, MA, USA) along with $10 \times$ reaction buffer with $\mathrm{MgCl}_{2}$ and $\mathrm{RNase}$ free water to make up the final volume $10 \mu \mathrm{l}$, kept at $37^{\circ} \mathrm{C}$ for $2 \mathrm{~h}$ incubation in water bath and were enzyme de activated by adding $1 \mu \mathrm{l}$ of $50 \mathrm{mM}$ EDTA and continued incubation at $60-65^{\circ} \mathrm{C}$ for $10 \mathrm{~min}$. The integrity, concentration and purity of RNA were assessed on $1 \%$ EtBr-stained agarose gel visualized under UV light and on a Nanodrop 2000 Spectrophotometer (Thermo Fisher Scientific) and stored at $-80^{\circ} \mathrm{C}$. The SCYLV primer was designed from the consensus coat protein regions through primer 3.0 and sigma oligo evaluator, named as SCYLV-FP (5'-CTGAGAATTCATGGATACGGGCGCTAACCGCTC-3') and SCYLV-RP (5'-CTGCAAGCTT TTATTTGGGATTCTGGAATA-3') which can amplify complete ORF 3 of coat protein gene were used in this study. One microgram of total RNA per reaction was reverse transcribed using RevertAid H Minus First Strand cDNA Synthesis Kit (MBI, Fermentas, Waltham, MA, USA), primed with 50 pmol of SCYLV-615R by following the manufacturer's protocol in a thermal cycler (Eppendorf, Hamburg, Germany). The PCR reaction was performed in a total volume of $25 \mu \mathrm{l}$ containing $2.5 \mu \mathrm{l}$ of $10 \times$ Taq buffer with $15 \mathrm{mM} \mathrm{MgCl}_{2}, 0.5 \mu 1$ of $10 \mathrm{mM}$ dNTP mix, $10 \mu \mathrm{M}$ of each forward and reverse primers, 1.25 units of Taq polymerase (Origin, Kerala, India), $2 \mu 1$ of cDNA and sterile MilliQ water to make up the final volume. The PCR programme was performed with initial denaturation 
at $94^{\circ} \mathrm{C}$ for $5 \mathrm{~min}$, followed by 35 cycles of denaturation at $94^{\circ} \mathrm{C}$ for $4 \mathrm{~min}$, annealing at $65^{\circ} \mathrm{C}$ for $1 \mathrm{~min}$, extension at $72^{\circ} \mathrm{C}$ for $1 \mathrm{~min}$ and final extension at $72^{\circ} \mathrm{C}$ for $10 \mathrm{~min}$. All the amplified products were run on $1.5 \%$ agarose gels stained with ethidium bromide $(0.5 \mu \mathrm{g} / \mathrm{ml})$ and gel images were documented in a gel documentation unit (G-BOX EF, Syngene, Cambridge, UK).

DNA extraction and nested PCR for phytoplasma diagnosis. Total genomic DNA was extracted from $0.5 \mathrm{~g}$ leaves, ground in liquid nitrogen by following the cetyl trimethyl ammonium bromide method (Doyle and Doyle, 1990), treated with RNase I (10 U/ $\mu$ l) (Thermo Fischer Scientific) and purified. The integrity, concentration and purity of DNA was assessed on $0.8 \% \mathrm{EtBr}$-stained agarose gel visualized under UV light and on a Nanodrop 2000 Spectrophotometer (Thermo Fisher Scientific) and stored at $-20^{\circ} \mathrm{C}$. Based on the genomic DNA concentration it was diluted up to $50 \mathrm{ng} / \mu \mathrm{l}$ for the PCR analysis. PCR was performed using the universal phytoplasma specific primers P1/P7 (Deng and Hiruki, 1991) in the first round PCR and R16F2n 5'-GAAACGACTGCTAAGACTGG-3' and R16R2 5'-TGACGGGCGGTGTGTACAAACCCCG-3' primer pairs were used in the nested PCR (Gunderson and Lee, 1996; Lee et al., 1993) for the amplification of both large (23S), small (16S), and 16S-23S ribosomal spacer regions. The PCR reaction was performed in a total volume of $25 \mu \mathrm{l}$ containing, $2.5 \mu \mathrm{l}$ of $10 \times$ Taq buffer with $15 \mathrm{mM}$ $\mathrm{MgCl}_{2}, 2 \mu \mathrm{l}$ of $2.5 \mathrm{mM} \mathrm{dNTP}$ mix, $10 \mu \mathrm{M}$ of each forward and reverse primers, 0.33 units of Taq polymerase (Origin), $1 \mu \mathrm{l}$ of genomic DNA and sterile MilliQ water to make up the final volume.

The PCR cyclic conditions for the P1/P7 primer was initial denaturation at $94^{\circ} \mathrm{C}$ for $5 \mathrm{~min}$, followed by 35 cycles of denaturation at $94^{\circ} \mathrm{C}$ for $30 \mathrm{~s}$, annealing at $56^{\circ} \mathrm{C}$ for 1 $\min 30 \mathrm{~s}$, extension at $72^{\circ} \mathrm{C}$ for $1 \mathrm{~min} 30 \mathrm{~s}$, and a final extension at $72^{\circ} \mathrm{C}$ for $15 \mathrm{~min}$ following that nested PCR was performed using the 1:10 dilution of $\mathrm{P} 1 / \mathrm{P} 7$ product with the same cyclic conditions except the annealing temperature at $58^{\circ} \mathrm{C}$ for $1 \mathrm{~min} 30 \mathrm{~s}$. Besides, a custom designed primer was synthesized through primer 3.0 and sigma oligo evaluator based on all the available SCYP sequence submissions at GenBank database for the SCYP diagnosis in the collected YL samples. The primers were named as YL FP1 (5'-CAATAGGTATGCTTAGGGAGGAGCTTGCGTCAC-3') and YL RP 1 (5'-CCTCCACTGTGTTTCTACAGCTTTGCAG-3'), initially standardized with gradient PCR and the cyclic conditions were initial denaturation at $94^{\circ} \mathrm{C}$ for $5 \mathrm{~min}$, followed by 35 cycles of denaturation at $94^{\circ} \mathrm{C}$ for $1 \mathrm{~min}$, annealing at $60^{\circ} \mathrm{C}$ for $1 \mathrm{~min} 30 \mathrm{~s}$, extension at $72^{\circ} \mathrm{C}$ for $1 \mathrm{~min} 30 \mathrm{~s}$ and a final extension at $72^{\circ} \mathrm{C}$ for 10 $\mathrm{min}$. All the three PCR amplified products were run on $1.2 \%$ agarose gels stained with ethidium bromide $(0.5 \mu \mathrm{g} / \mathrm{ml})$ and gel documented. The positive samples were eluted from the low melting agarose gel using GenElute Gel Extraction Kit (Sigma), purified and was further checked in agarose gel and quantified in Nanodrop 2000 Spectrophotometer (Thermo Fisher Scientific). The positive samples were sent for double pass sequencing to commercial sequencing firm Bioserve Technologies, Hyderabad, India.

Restriction fragment length polymorphism (RFLP) analyses. Restriction fragment length polymorphism analysis was performed to the nested PCR product of the YL samples amplified by R16F2n/R16R2n primers. The restriction enzymes Bfa I (FspB I), Msp I (Hpa II), Mse I,

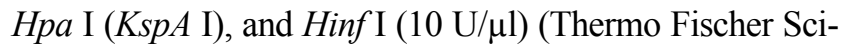
entific) were selected based on the in silico virtual RFLP iphyclassifier enzymes list to identify the phytoplasma. The reaction was performed with reaction volume of 20 $\mu \mathrm{l}$ containing $2 \mu \mathrm{l}$ of $10 \times$ restriction digestion buffer with bovine serum albumin (Tango/R/B buffers according to the enzymes), $3 \mu \mathrm{l}$ of PCR product (500-1,000 ng/ $\mu \mathrm{l}), 2 \mu \mathrm{l}$ of restriction enzymes and sterile MilliQ water to make up the final volume kept at $37^{\circ} \mathrm{C}$ for $2 \mathrm{~h}$ incubation in water bath and were run on $1.5 \%$ agarose gels and documented. SCGS phytoplasma cv. CoV 92101 was used as a positive control to confirm the restriction pattern of the phytoplasma in YL samples.

Phylogenetic analysis. Quality of all the samples sequences were confirmed based on the q-value $(>30)$. All the sequences were subjected into BLASTn searches at NCBI website (Altschul et al., 1990) and pair wise multiple sequence alignment of the selected sequences were made through Bio edit (Hall, 1999) and maximum likelihood Tamura-Nei model based phylogenetic tree analysis was performed with nearest neighbour interchange tree options (MEGA X v.10.1.6) with 1,000 bootstrap replications to know the evolutionary genetic relatedness (Kumar et al., 2018) of all the samples collected from different varieties and fields.

\section{Results}

Out of 64 samples tested, SCYLV was detected from 48 samples with the expected amplification of 591 bp in RTPCR assays (Fig. 2). In case of phytoplasma, none of the samples had shown any amplification in the first round of direct PCR using P1/P7 primers except the positive SCGS 


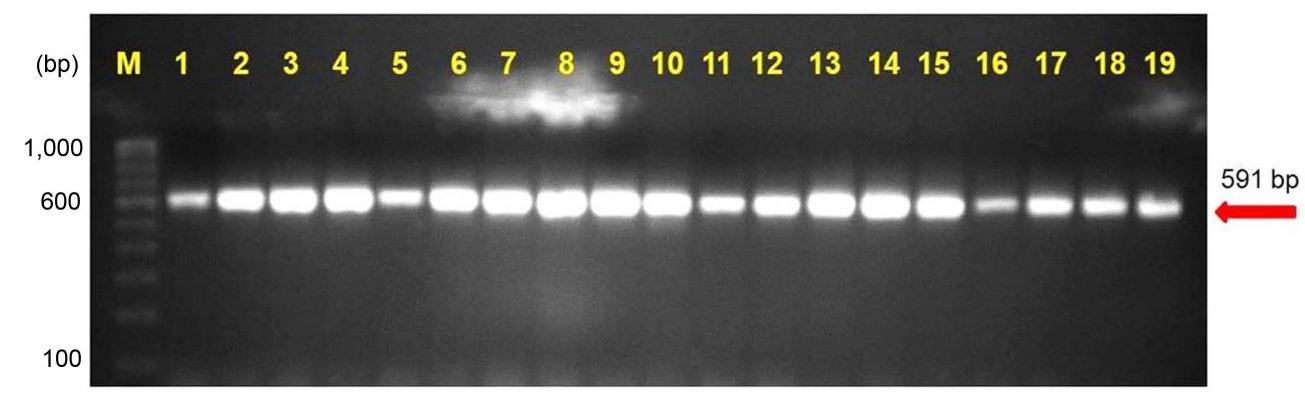

Fig. 2. Specific amplification SCYLV-CP gene by RT-PCR assay from different sugarcane cultivars. SCYLV, Sugarcane yellow leaf virus; RT-PCR, reverse transcription PCR.

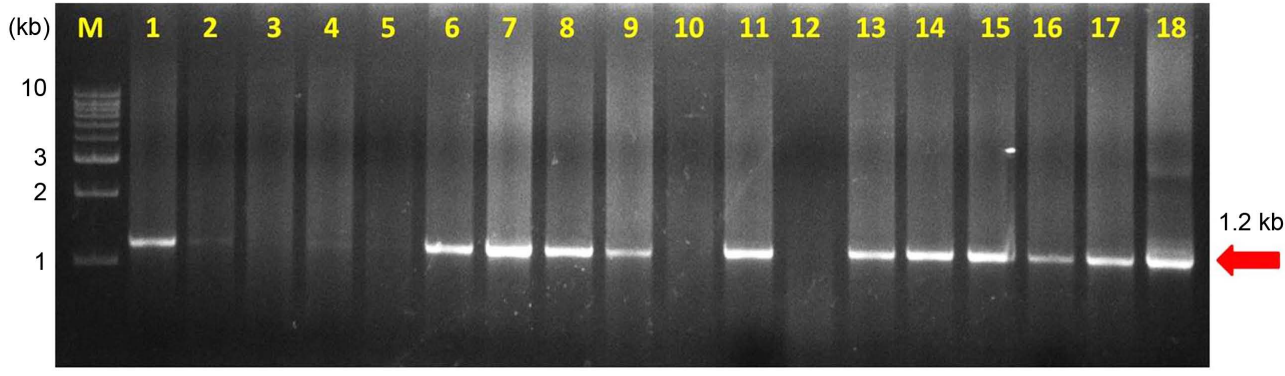

Fig. 3. Detection of phytoplasma in yellow leaf affected sugarcane cultivars by nested PCR using R16F2n/R16R2.

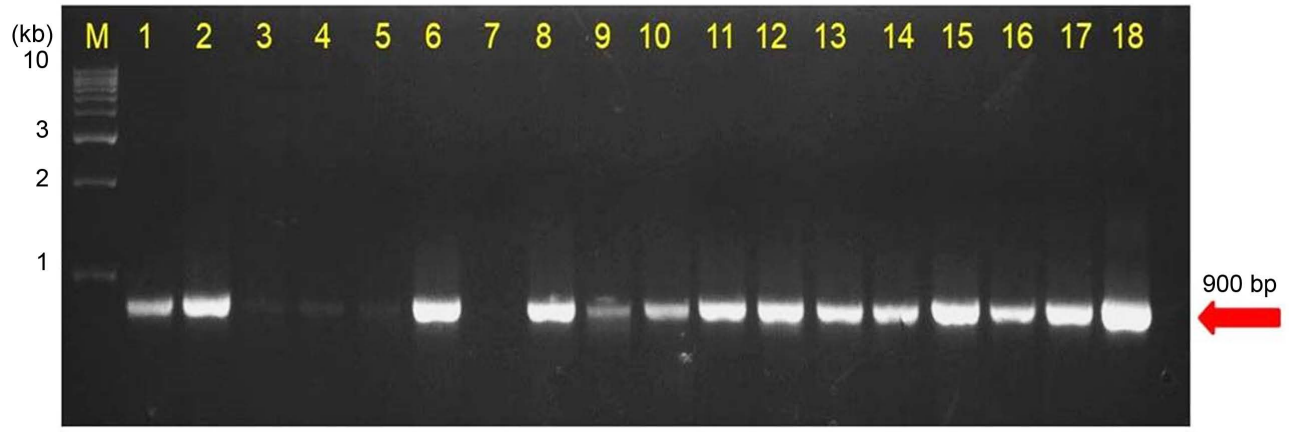

Fig. 4. Detection of phytoplasma in YL affected sugarcane cultivars by nested PCR using YLD FP1/RP1 primers.

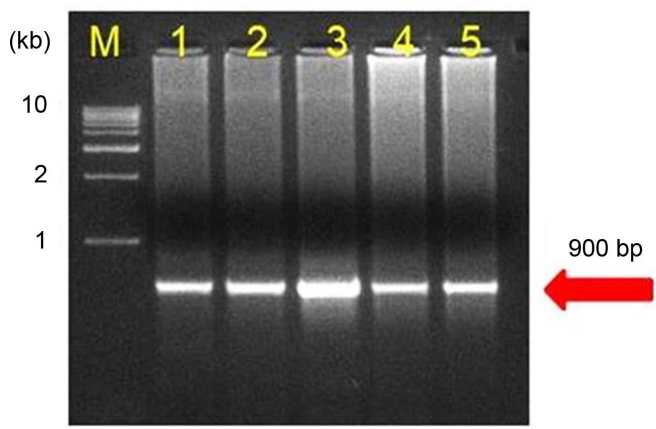

Fig. 5. Detection of sugarcane grassy shoot-phytoplasma in different tissues of yellow leaf affected sugarcane cv Co 10031 by nested PCR assay.

phytoplasma cv. CoV 92101. Whereas, in nested PCR analysis 14 samples were found positive to both the phytoplasma primers R16F2n/R16R2 and YL FP1/RP1 with the expected amplification of 1,200 bp and $900 \mathrm{bp}$, respectively (Figs. 3 and 4). The YL affected cv Co 10031 leaf, root and internode (3rd, 6th, and 9th) samples were found positive to YL FP1/RP1 phytoplasma primers with the expected amplification of 900 bp (Fig. 5). The primers YL FP1/ RP1 designed from ribosomal RNA regions from SCYP consensus sequences were found better than R16F2n/ $\mathrm{R} 16 \mathrm{R} 2$ in terms of intense amplification and wide sample coverage. Out of 64 samples tested, YL FP1/RP1 shown positive to 21 samples and R16F2n/R16R2 shown positive to 15 samples and both the primers shown intense amplification to 13 samples viz. $57 \mathrm{NG} \mathrm{56,} \mathrm{Co} \mathrm{449,} \mathrm{Co} \mathrm{6304,}$ Co 86010, Co 86032, Co 87269, Co 10031, CoC 671, CoC 99061, CoPant 94211, CoS 8436, CoV 92102, and CoV 94101. Mixed infection of SCYLV and SCGS phytoplasma was estimated as $32.8 \%$ in YL affected plants. All the genomic sequences analyzed through Blastn had shown $98.92 \%$ to $99.82 \%$ similarity with $98.25-100 \%$ query coverage to other SCGS phytoplasma isolates, amongst maximum similarity was found with sugarcane SCGS phytoplasma sequences submitted from India, Thailand and with 
Table 2. SCGS phytoplasma sequences from YL plants submitted at NCBI, GenBank

\begin{tabular}{rlllll}
\hline No. & Isolate name & $\begin{array}{l}\text { GenBank accession no. } \\
(\text { R16F2n/R16R2 })\end{array}$ & No. & Isolate name & $\begin{array}{l}\text { GenBank accession no. } \\
(\text { YL FP1/RP1) }\end{array}$ \\
\hline 1 & CB-57NG56 & MN904473.1 & 11 & CB-Co 86010 & MN904486.1 \\
2 & CB-CoC 0106 & MN904472.1 & 12 & CB-Co 6304 & MN904476.1 \\
3 & CB-CoC 671 & MN904471.1 & 13 & CB-CoC 0106 & MN904482.1 \\
4 & CB-CoV 92101 & MN904470.1 & 14 & CB-Co 10031 & MN904475.1 \\
5 & CB-CoC 99061 & MN904469.1 & 15 & CB-CoC 99061 & MN904479.1 \\
6 & CB-CoS 8436 & MN904468.1 & 16 & CB-CoS 8436 & MN904478.1 \\
7 & CB-Co 86010 & MN904467.1 & 17 & CB-CoV 92101 & MN904480.1 \\
8 & CB-Co Pant 84211 & MN904466.1 & 18 & CB-CoC 671 & MN904481.1 \\
9 & CB-Co 6304 & MN904465.1 & 19 & CB-CoPant 84211 & MN904485.1 \\
10 & CB-Co10031 & MN904464.1 & 20 & CB-57NG56 & MN904483.1 \\
\hline
\end{tabular}

SCGS, sugarcane grassy shoot; YL, yellow leaf.

white leaf phytoplasma from Sri Lanka (MN174860.2). All the sequences of both the primers have been submitted at GenBank with the accession numbers MN904464.1 to MN904486.1 (Table 2). Since, the SCGS phytoplasma was confirmed in the YL plants, its similarity with the available 22 SCYP sequences as well as from other SCGS and sugarcane white leaf (SCWL) phytoplasma sequences submitted from different countries were analyzed for evolutionary genetic relatedness. But, the SCYP sequences submitted from Cuba during the years 2001 (2 numbers), 2003 and 2005 and one SCYP isolate from Africa (Cronje at al., 1999 ) were $<250$ nucleotides in length compared to others hence, were not considered for the analysis (Table 3).

The results of the remaining 15 SCYP sequences and other SCGS and SCWL phytoplasma sequences representatively taken from different countries such as India, Thailand, Hawaii, Sri Lanka, China, and Vietnam along with phytoplasma sequences obtained from the YL plants in this study were subjected to phylogenetic analyses. The results of 31 sequences segregated into three major clusters, the first one contained all the SCGS, SCWL phytoplasmas belonging to $16 \mathrm{SrXI}$ (Rice yellow dwarf) group and the second one contained all the SCYP belonging to 16SrI (aster yellows; $\mathrm{Ca}$. Phytoplasma asteris) group and the third one contained the SCYP from South Africa and Cuba, both shared the maximum similarity with $16 \mathrm{SrXI}$ group. All the SCGS phytoplasma used in this study and SCWL phytoplasma reported from Thailand, Vietnam, and China showed highest similarity of $>80 \%$ with SCYP India, 2014 followed by SCYP Cuba, 2010 (HM804282.1) and SCYP Brazil, 2009. Acholeplasma sp. was used as out group in the tree (Fig. 6, Supplementary Table 1).

Of the total 22 SCYP sequences, 20 only were analyzed in pairwise multiple sequence alignment using Clustal W (leaving the two sequences submitted from India during the year 2016 from sec A gene and LeucyltRNA gene partial sequences) in that, the South African sequence submitted by Cronje in the year 2000 (AF056094.1) has the maximum length i.e. 1,929 nucleotides. Hence, all the SCYP sequences were compared by taking that one as a reference in SCGS, sugarcane grassy shoot; YL, yellow leaf.that the Cuban isolate (HM 804282.1) had shown highest similarity with this sequence. The results of RFLP analysis showed that all the YL samples nested PCR product restriction profiles were as similar as to SCGS phytoplasma cv. CoV 92101 in all the enzymes tested and the enzymes $\operatorname{Hinf}$ I and $B f a \mathrm{I}$ had shown intense digestion. However, in Hpa I, one sample restriction pattern was different compared to others may be due star activity or over digestion (Fig. 7).

\section{Discussion}

SCYLV was confirmed as the causative agent of the YL disease in Indian cultivars and its characterization was done up to complete genome level and existence of different genotypes of the virus was reported including the new genotype SCYLV-IND (Chinnaraja et al., 2013, Viswanathan et al., 2008). Since mixed infections of SCYLV and SCYP were reported in some countries, we suspected the possible association of SCYP in YL of sugarcane hence, investigated on their probable mixed infections in Indian sugarcane cultivars, and importantly to develop effective diagnostics and to characterize exact $\mathrm{Ca}$. phytoplasma taxon associated with Indian YL disease. SCYP was first reported in South Africa and Cuba (Arocha et al., 1999; Cronje et al., 1998), and in Mauritius mixed infections of SCYLV and SCYP 


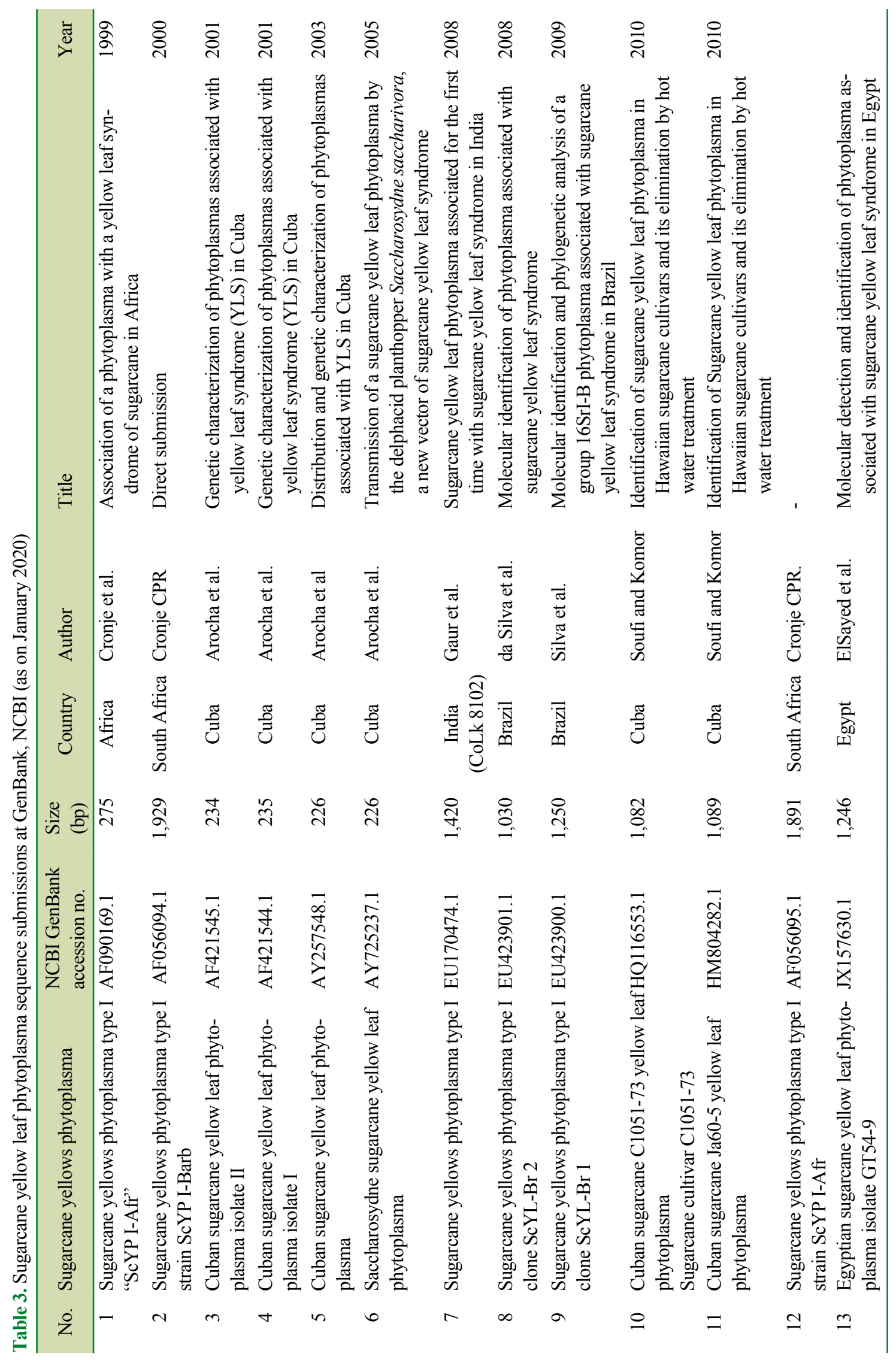


Nithya et al.

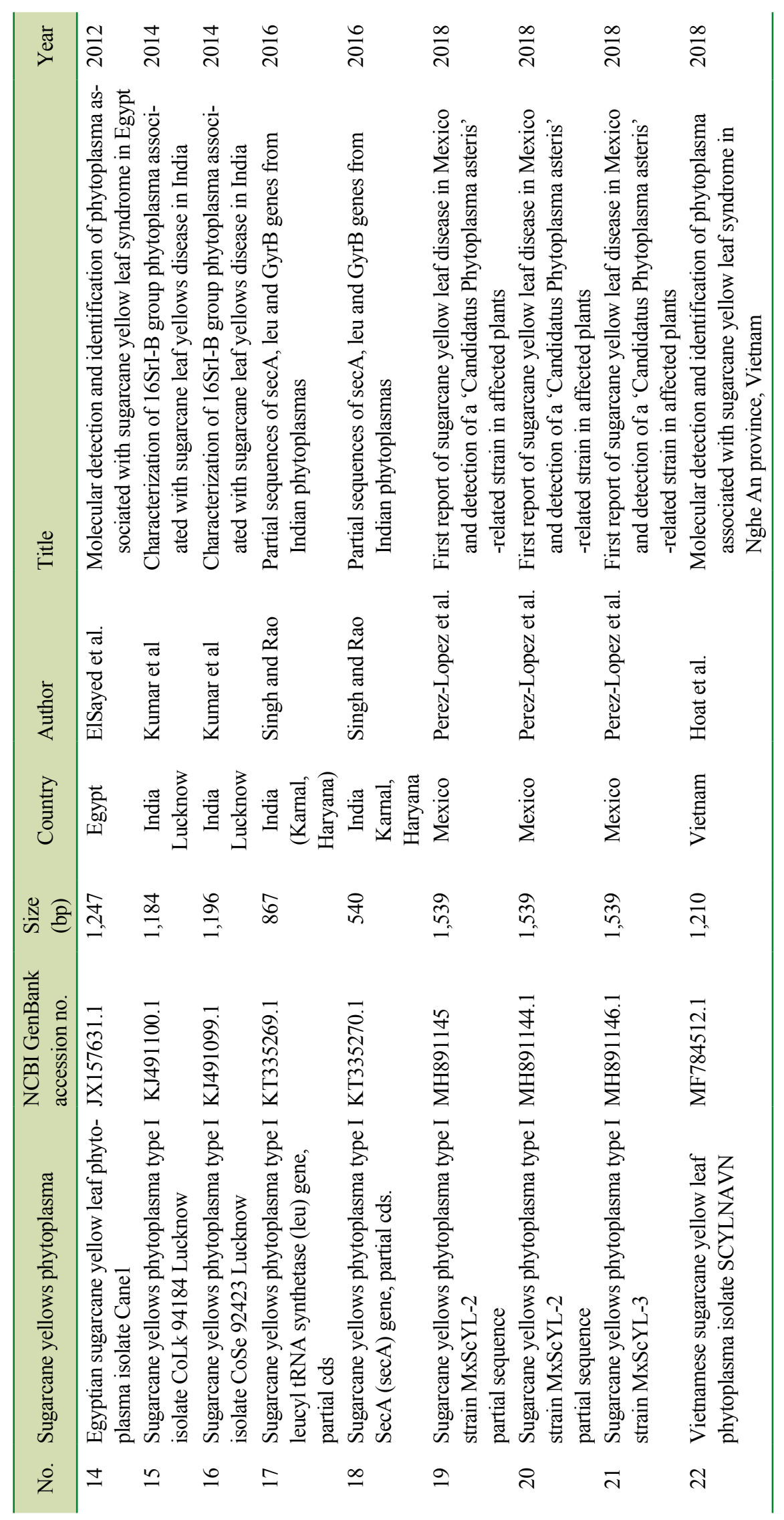




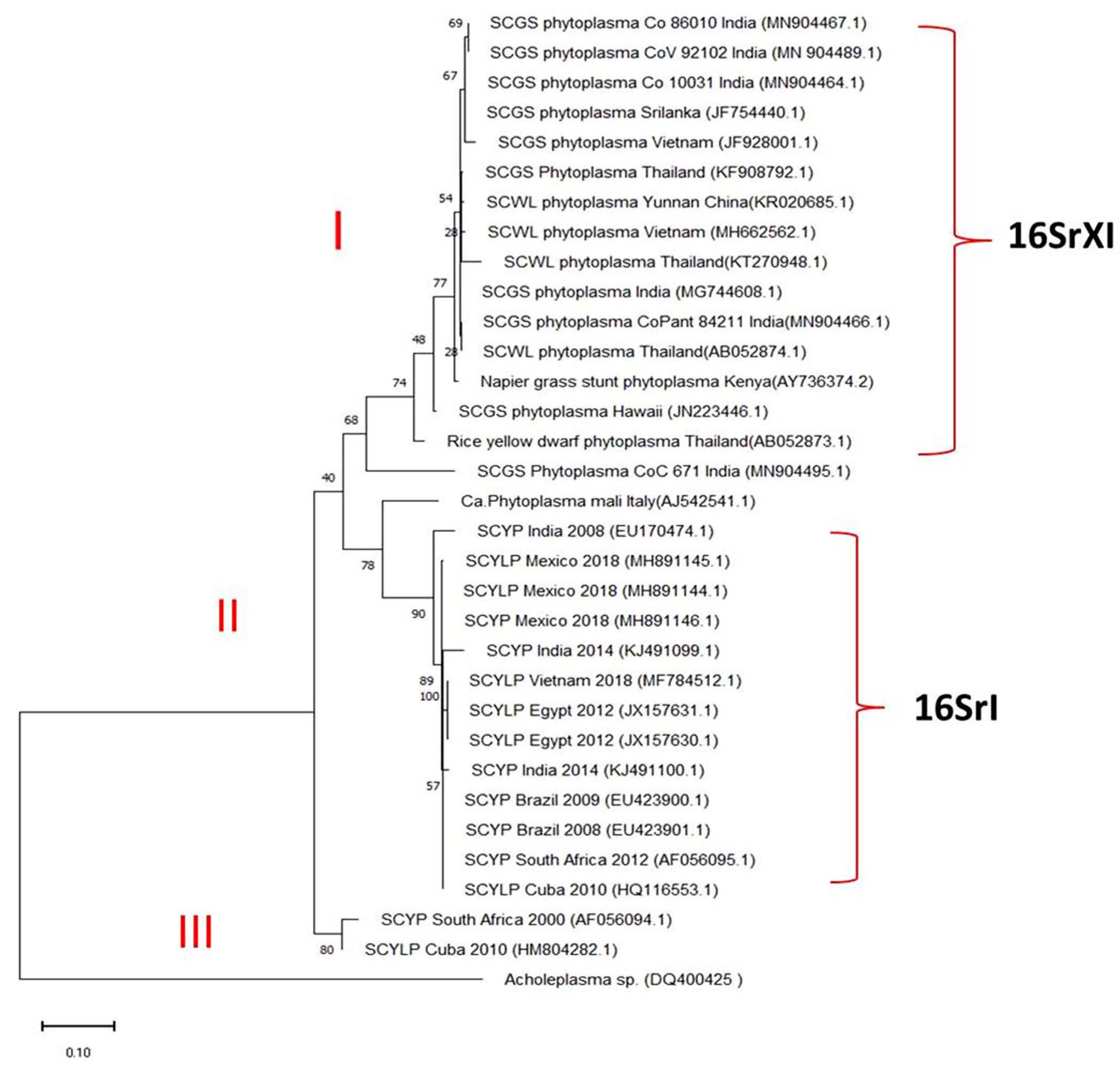

Fig. 6. Phylogenetic tree was constructed by maximum likelihood neighbour joining method using MEGA-X v10.1.6 showing the relationship between the sugarcane grassy shoot phytoplasma and sugarcane yellow leaf phytoplasma. Bootstrap values were expressed as percentage of 1,000 replications and branch lengths are proportional to the number of substitutions. Acholeplasma sp. was used to out group the tree.

were reported (Aljanabi et al., 2001; Parmessur et al., 2002). In Africa, two different phytoplasma viz. western Xdisease and SCWL phytoplasma were reported (Aljanabi et al., 2001; Cronje and Bailey, 1999) with 98.8\% sequence similarity. In Australia, the single sugarcane plant was reported with multiple infections of two or more distinctly different phytoplasma groups, most of them were infected by the tomato big bud (TBB) and less frequent were sun hemp witches'-broom (SUNHP) of the Faba Bean Phyllody group, stylosanthes little leaf (StLL) of the loofah witches-broom (LfWB) group and Maryland aster yellows (AY1) of the AY group (Tran-Nguyen et al., 2000). Also, the less frequently detected phytoplasmas were mainly from asymptomatic plants while the TBB phytoplasma was detected with equal frequency in both symptomatic and asymptomatic plants (Schneider et al., 1999). Recently, ' $C a$. P. asteris' subgroup (16Sr I-B) in Brazil and Egypt (Silva et al., 2009; ElSayed and Boulila, 2014); white leaf phytoplasma in Thailand (Soufi et al., 2013); latent infections of 16SrI (aster yellows) and 16SrXI (Rice yellow dwarf) groups in asymptomatic Hawaiian sugarcane cultivars (Soufi and Komor, 2014) and Egyptian sugarcane cultivars based on sequencing and RFLP analyses (E1Sayed et al., 2016) were reported from YL affected plants. In India, 16SrXII (Stolbur group) (Gaur et al., 2008) and 16SrI-B (Aster Yellow group) (Kumar et al., 2015) were reported 

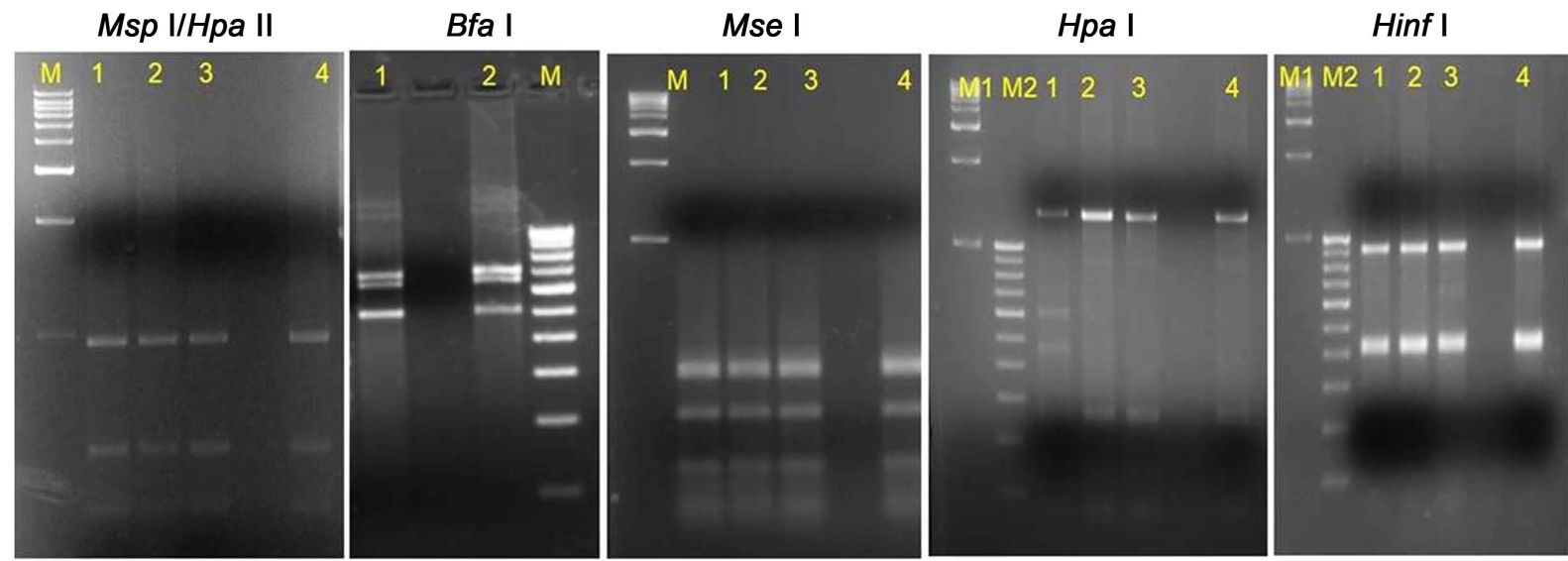

Fig. 7. Restriction fragment length polymorphism patterns of phytoplasma from yellow leaf affected sugarcane samples. M1, M2, $1 \mathrm{~kb}$ and $100 \mathrm{bp}$ ladder (GeNei StepUp, India); lane 1-3, restriction digestion of nested PCR product of yellow leaf samples DNA amplified by R16F2n/R16R2 primers; lane 4, positive sugarcane grassy shoot (SCGS) sample cv CoV 92101; except 7b) Bfa I where, lane 2 is SCGS sample cv CoV 92101.

from sub-tropical cvs CoLk 8102, CoLk 94184, and CoSe 92423.

As on date, SCYP has been reported in seven countries viz. South Africa, Cuba, Brazil, Egypt, Mexico, India and recently in Vietnam. Although 22 SCYP partial sequences were submitted in GenBank database, no reports are available on any phytoplasma specific symptom changes in the YL plants other than the characteristic SCYLV symptoms. Also the first reports from South Africa and Cuba have not ruled out absence of SCYLV from the YL affected plants
(Arocha et al., 1999; Cronje et al., 1998) hence, all these SCYP reports speculate that there could have been SCYLV infection with additional infection of phytoplasma as reported by different researchers.

Despite the report of different groups of phytoplasma as mixed infections, the white leaf phytoplasma was reported along with that in most of the countries. In sugarcane, grassy shoot disease (GSD) and white leaf disease (WLD) both were named according to its symptom expression on the infected pants. In case of GSD, the infected plant
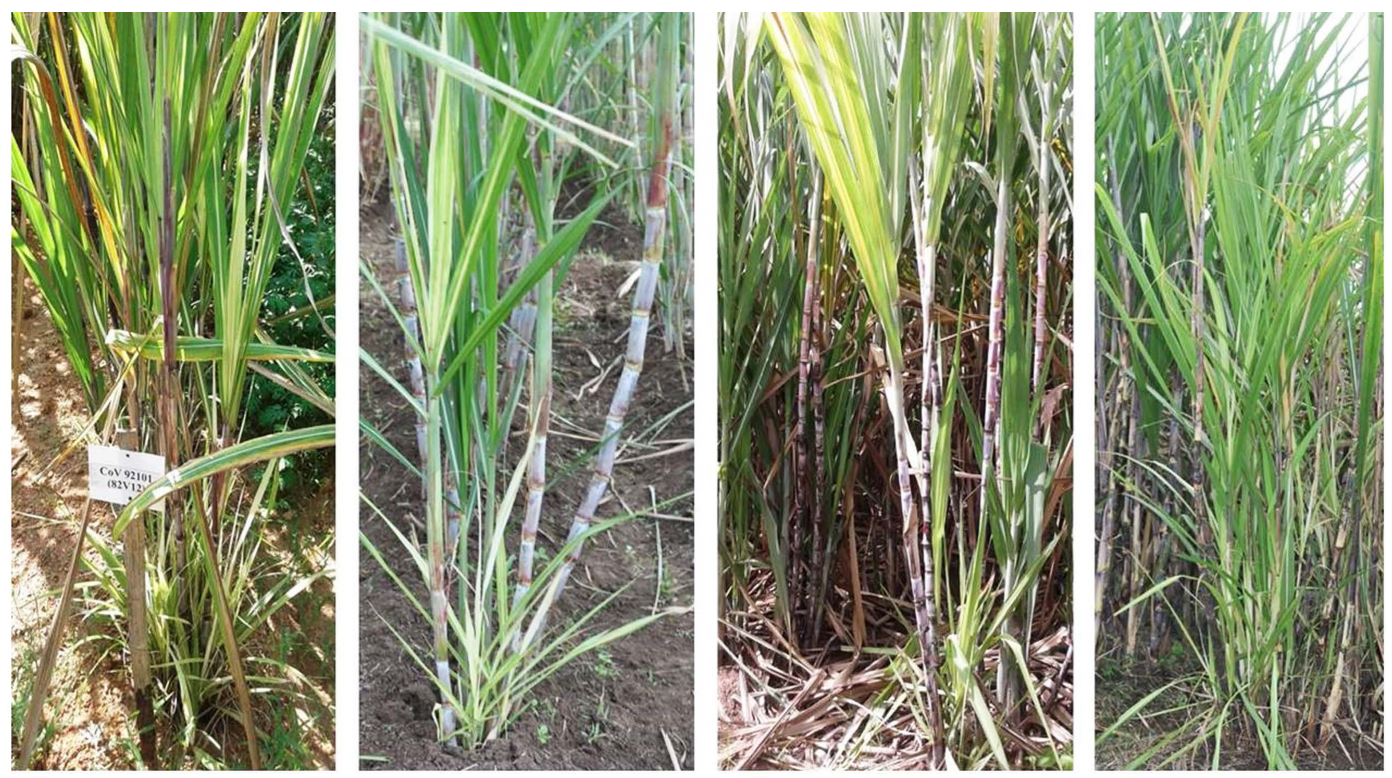

Fig. 8. Different sugarcane varieties showing both yellow leaf and grassy shoot symptoms in the same clump. Top leaf canopy showing the typical yellowing of leaf mid rib with yellow leaf symptoms and the same bottom were with chlorotic leaves and thin grassy tillers of grassy shoot disease symptoms. 
does not produce any millable canes, instead produces only grassy chlorotic tillers hence, named as grassy shoot disease (Viswanathan, 2000) and in case of WLD, the infected clump produces the same symptom with complete white/creamy tillers. In India, two kinds of phenotypes are very common and WLD is a misnomer for Indian scenario (Nasare et al., 2007; Viswanathan et al., 2011). However, both are belonging to the same rice yellow dwarf/16SrXI group. WLD occurrence is widely reported in South East Asian countries viz. Indonesia, Thailand, Sri Lanka, and also in China and GSD occurrence is reported more from India only.

The results obtained in this work clearly evidenced that YL in India is caused only by SCYLV and the phytoplasma associated in the YL plant is SCGS phytoplasma which has been confirmed based on the sequencing results, phylogenetic analysis as well as by RFLP using specific enzymes. In support of our findings, presence of both YL and GSD symptoms in the same clumps were recorded in many popular varieties such as, Co 86032, Co 88028, CoV 92101, CoV 94101, CoV 89101, CoV 09356, etc. in both plant and ratoon crops in the institute fields as well as in farmers' holdings in that only few millable cane formation used to be there and the remaining tillers show grassy shoot symptoms (Fig. 8) whereas, in some cases, the sett material taken from the severely affected YL plant or the ratoon of the YL affected clump shows the GSD expression even in the tillering phase of the crop due to build of high phytoplasma titre in the previous crop. Although our results were contradictory with SCYP (16Sr-I aster yellow group) association in YL plants of sub-tropical cultivars, only SCGS phytoplasma association was confirmed from both tropical and sub-tropical cultivars in India. Such type of both group of phytoplasma associations (16SrI and 16SrXI) were earlier reported from YL plants in Hawaii (Soufi and Komor, 2014) and, in Egypt, SCYLV as well as 16SrI and 16SrXI groups of phytoplasma were reported on cvs H73-6110, G03-47, G84-47 (ElSayed et al., 2016). All the sugarcane viruses Sugarcane Mosaic Virus (SCMV), Sugarcane Streak Mosaic Virus (SCSMV), and SCYLV were diagnosed even in asymptomatic plants in RT-PCR assays (Viswanathan et al., 2008, 2009; Viswanathan, 2016) due to latent stage or low titre of viruses, the same can be applicable to SCGS phytoplasma. Both, SCYLV and SCGS phytoplasma are phloem limited pathogens and the SCYLV titre might be more than the SCGS phytoplasma in all the collected YL plants in this study. Because of mixed infections of both the pathogens and further inoculum build up in subsequent ratoons, the growth and yield of many high yield and high sugar varieties were reduced.
Non-fungal pathogens, especially virus and bacteria are associated with such varietal degeneration in India; pathogen elimination through tissue culture combined with molecular diagnosis has addressed such constraints under field conditions (Rao et al., 2012; Viswanathan, 2016; Viswanathan and Rao, 2011; Viswanathan et al., 2018). In this regard, our study clearly indicates SCYLV only causes the YL disease in sugarcane and SCYP association is not found with the disease.

Overall, the study has revealed lack of evidences for the occurrences of SCYP in YL affected sugarcane in India, the major sugarcane producer in the world after Brazil. A clarity on the $\mathrm{YL}$ associated pathogen has been brought out and incidentally we could detect mixed infections of SCYLV and SCGS-phytoplasma in YL affected sugarcane plants. Further studies are required on the combined infections of these phloem limiting pathogens in sugarcane on YL symptom expression, its severity and their interactions.

\section{Acknowledgments}

The authors thank the Director, ICAR- Sugarcane Breeding Institute, Coimbatore for providing all the facilities.

\section{Electronic Supplementary Material}

Supplementary materials are available at The Plant Pathology Journal website (http://www.ppjonline.org/).

\section{References}

Aljanabi, S. M., Parmessur, Y., Moutia, Y., Saumtally, S. and Dookun, A. 2001. Further evidence of the association of a phytoplasma and a virus with yellow leaf syndrome in sugarcane. Plant Pathol. 50:628-636.

Altschul, S. F., Gish, W., Miller, W., Myers, E. W. and Lipman, D. J. 1990. Basic local alignment search tool. J. Mol. Biol. 215:403-410.

Arocha, Y., Gonzalez, L., Peralta, E. L. and Jones, P. 1999. First report of virus and phytoplasma pathogens associated with yellow leaf syndrome of sugarcane in Cuba. Plant Dis. 83:1177.

Arocha, Y., Jones, P., Sumac, I. and Peralta, E. L. 2000. Detection of phytoplasmas associated to yellow leaf syndrome in Cuba. Revi. Prot. Veg. 15:81-86.

Bertaccini, A., Duduk, B., Paltrinieri, S. and Contaldo, N. 2014. Phytoplasmas and phytoplasma diseases: a severe threat to agriculture. Am. J. Plant Sci. 5:1763-1788.

Chinnaraja, C. and Viswanathan, R. 2015a. Quantification of Sugarcane yellow leaf virus in sugarcane following transmission through aphid vector, Melanaphis sacchari. Virusdisease 26:237-242. 
Chinnaraja, C. and Viswanathan, R. 2015b. Variability in yellow leaf symptom expression caused by the Sugarcane yellow leaf virus and its seasonal influence in sugarcane. Phytoparasitica 43:339-353.

Chinnaraja, C., Viswanathan, R., Karuppaiah, R., Bagyalakshmi, K., Malathi, P. and Parameswari, B. 2013. Complete genome characterization of Sugarcane yellow leaf virus from India: evidence for RNA recombination. Eur. J. Plant. Pathol. 135:335-349.

Chinnaraja, C., Viswanathan, R., Sathyabhama, M., Parameswari, B., Bagyalakshmi, K., Malathi, P. and Neelamathi, D. 2014. Quantification of Sugarcane yellow leaf virus in in vitro plantlets and asymptomatic plants of sugarcane by RT-qPCR. Curr. Sci. 106:729-734.

Comstock, J. C., Irey, M. S., Lockhart, B. E. L. and Wang, Z. K. 1998. Incidence of yellow leaf syndrome in CP cultivars based on polymerase chain reaction and serological techniques. Sugar Cane 4:21-24.

Cronje, C. P. R. and Bailey, R. A. 1999. Association of phytoplasmas with yellow leaf syndrome of sugarcane. Proc. Int. Soc. Sugar Cane Technol. 23:373-381.

Cronje, C. P. R., Tymon, A. M., Jones, P. and Bailey, R. A. 1998. Association of a phytoplasma with a yellow leaf syndrome of sugarcane in Africa. Ann. Appl. Biol. 133:177-186.

Deng, S. and Hiruki, C. 1991. Amplification of 16S rRNA genes from culturable and non culturable mollicutes. J. Microbiol. Methods 14:53-61.

Doyle, J. J. and Doyle, J. L. 1990. Isolation of plant DNA from fresh tissue. Focus 12:13-15.

ElSayed, A. I. and Boulila, M. 2014. Molecular identification and phylogenetic analysis of sugarcane yellow leaf phytoplasma (SCYLP) in Egypt. J. Phytopathol. 162:89-97.

ElSayed, A. I., Soufi, Z., Wahdan, K. M. and Komor, E. 2016. Detection and characterization of phytoplasma and Sugarcane yellow leaf virus associated with leaf yellowing of sugarcane. J. Phytopathol. 164:217-225.

Gaur, R., Raizada, R. and Rao, G. P. 2008. Sugarcane yellow leaf phytoplasma associated for the first time with sugarcane yellow leaf syndrome in India. New Disease Rep. 16:43.

Gaur, R. K., Singh, A. P., Singh, M., Singh, A. K., Upadhyaya, P. P. and Rao, G. P. 2003. Reliability of serological identification of sugarcane mosaic potyvirus (SCMV) and sugarcane yellow leaf luteovirus (SCYLV) from cane stalk juice. Sugar Cane Int. 5:18-21.

Gundersen, D. E. and Lee, I. M. 1996. Ultrasensitive detection of phytoplasmas by nested-PCR assays using two universal primer pairs. Phytopathol. Mediterr. 35:144-151.

Hall, T. A. 1999. BioEdit: a user-friendly biological sequence alignment editor and analysis program for Windows 95/98/ NT. Nucleic Acids Symp. Ser. 41:95-98.

Kirdat, K., Tiwarekar, B., Thorat, V., Narawade, N., Dhotre, D., Sathe, S., Shouche, Y. and Yadav, A. 2020. Draft genome sequences of two phytoplasma strains associated with sugarcane grassy shoot (SCGS) and bermuda grass white leaf
(BGWL) diseases. Mol. Plant-Microbe Interact. 33:715-717.

Kumar, S., Tiwari, A. K., Holkar, S. K., Duttamajumder, S. K. and Rao, G. P. 2015. Characterization of a 16SrI-B subgroup phytoplasma associated with Sugarcane leaf yellows disease in India. Sugar Tech 17:156-161.

Kumar, S., Stecher, G., Li, M., Knyaz, C. and Tamura, K. 2018. MEGA X: molecular evolutionary genetics analysis across computing platforms. Mol. Biol Evol. 35:1547-1549.

Lee, I. M., Hammond, R. W., Davis, R. E. and Gundersen, D. E. 1993. Universal amplification and analysis of pathogen 16S rDNA for classification and identification of mycoplasmalike organisms. Phytopathology 83:834-842.

Lehrer, A. T., Kusalwong, A. and Komor, E. 2008. High incidence of Sugarcane yellow leaf virus (SCYLV) in sugar plantations and germplasm collections in Thailand. Australas. Plant Dis. Notes 3:89-92.

Nasare, K., Yadav, A., Singh, A. K., Shivasharanappa, K. B., Nerkar, Y. S. and Reddy, V. S. 2007. Molecular and symptom analysis reveal the presence of new phytoplasmas associated with sugarcane grassy shoot disease in India. Plant Dis. 91:1413-1418.

Parmessur, Y., Aljanabi, S., Saumtally, S. and Dookun-Saumtally, A. 2002. Sugarcane yellow leaf virus and sugarcane yellows phytoplasma: elimination by tissue culture. Plant Pathol. 51:561-566.

Rao, G. P., Gaur, R. K., Singh, M., Srivastava, A. K., Virk, K. S., Singh, N., Viswanathan, R., Patil, A. S. and Jain, R. K. 2000. Occurrence of sugarcane yellow leaf virus in India. Sugar Tech 2:37-38.

Rao, G. P., Madhupriya, Thorat, V., Manimekalai, R., Tiwari, A. K. and Yadav, A. 2017. A century progress of research on phytoplasma diseases in India. Phytopathogenic Mollicutes 7:1-38.

Rao, G. P., Madhupriya, Tiwari, A. K., Kumar, S. and Baranwal, V. K. 2014. Identification of sugarcane grassy shoot-associated phytoplasma and one of its putative vectors in India. Phytoparasitica 42:349-354.

Rao, G. P., Mall, S. and Marcone, C. 2012. Recent biotechnological approaches in diagnosis and management of sugarcane phytoplasma diseases. In: Functional plant science and biotechnology. Recent trends in biotechnology and microbiology, Vol. 6, special issue 2, eds. by R. Viswanathan and A. R. Sundar, pp. 19-29. Global Science Books, New York, USA.

Rassaby, L., Girard, J.-C., Lemaire, O., Costet, L., Irey, M. S., Kodja, H., Lockhart, B. E. L. and Rott, P. 2004. Spread of Sugarcane yellow leaf virus in sugarcane plants and fields on the island of Réunion. Plant Pathol. 53:117-125.

Schenck, S. 1990. Yellow Leaf Syndrome: A New Disease of Sugarcane. Report of HSPA Experiment Station. Hawaii Sugar Planters Association, Honolulu, HI, USA. 98 pp.

Schneider, B., Padovan, A., De La Rue, S., Eichner, R., Davis, R., Bernuetz, A. and Gibb, K. S. 1999. Detection and differentiation of phytoplasmas in Australia: an update. Aust. J. Agric. Res. 50:333-342.

Silva, E. G., Bedendo, I. P., Casagrande, M. V. and Moraes, V. A. 
2009. Molecular identification and phylogenetic analysis of a group 16SrI-B phytoplasma associated with sugarcane yellow leaf syndrome in Brazil. J. Phytopathol. 157:771-774.

Soufi, Z. and Komor, E. 2014. Latent infection of asymptomatic Hawaiian sugarcane cultivars with $16 \mathrm{SrI}$ and $16 \mathrm{SrXI}$ phytoplasmas. J. Gen. Plant Pathol. 80:255-263.

Soufi, Z., Sakuanrungsirikul, S., Wongwarat, T., Hamarn, T., Srisink, S. and Komor, E. 2013. Sugarcane yellow leaf symptomatic plants in Thailand are infected by white leaf phytoplasma, not by leaf yellows phytoplasma. Australas. Plant Pathol. 42:723-729.

Tran-Nguyen, L., Blanche, K. R., Egan, B. and Gibb, K. S. 2000. Diversity of phytoplasmas in northern Australian sugarcane and other grasses. Plant Pathol. 49:666-669.

Viswanathan, R. 2000. Grassy shoot. In: A guide to sugarcane diseases, eds. by P. Rott, R. A. Bailey, J. C. Comstock, B. J. Croft and A. S. Saumtally, pp. 215-220. CIRAD, Montpellier, France.

Viswanathan, R. 2002. Sugarcane yellow leaf syndrome in India: incidence and effect on yield parameters. Sugar Cane Int. 20:17-23.

Viswanathan, R. 2016. Varietal degeneration in sugarcane and its management in India. Sugar Tech 18:1-7.

Viswanathan, R. and Balamuralikrishnan, M. 2004. Detection of Sugarcane yellow leaf virus, the causal agent of yellow leaf syndrome in sugarcane by DAS-ELISA. Arch. Phytopathol. Plant Prot. 37:169-176.

Viswanathan, R., Balamuralikrishnan, M. and Karuppaiah, R. 2006. Yellow leaf disease of sugarcane: occurrence and impact of infected setts on disease severity and yield. Proc. Sugar Technol. Assoc. India 67:74-89.

Viswanathan, R., Balamuralikrishnan, M. and Karuppaiah, R.
2008. Identification of three genotypes of sugarcane yellow leaf virus causing yellow leaf disease from India and their molecular characterization. Virus Genes 37:368-379.

Viswanathan, R., Chinnaraja, C., Karuppaiah, R., Kumar, V. G., Rooba, J. J. and Malathi, P. 2011. Genetic diversity of sugarcane grassy shoot (SCGS)-phytoplasmas causing grassy shoot disease in India. Sugar Tech 13:220-228.

Viswanathan, R., Chinnaraja, C., Malathi, P., Gomathi, R., Rakkiyappan, P., Neelamathi, D. and Ravichandran, V. 2014. Impact of Sugarcane yellow leaf virus (ScYLV) infection on physiological efficiency and growth parameters of sugarcane under tropical climatic conditions in India. Acta Physiol. Plant. 36:1805-1822.

Viswanathan, R., Karuppaiah, R., Malathi, P., Kumar, V. G. and Chinnaraja, C. 2009. Diagnosis of Sugarcane yellow leaf virus in asymptomatic sugarcane by RT-PCR. Sugar Tech 11:368-372.

Viswanathan, R., Malathi, P. and Neelamathi, D. 2018. Enhancing sugarcane yield per hectare through improved virus-free seed nursery programme. ICAR NEWS 24:4-5.

Viswanathan, R., Padmanaban, P., Mohanraj, D., Ramesh Sundar, A. and Premachandran, M. N. 1999. Suspected yellow leaf syndrome in sugarcane. Sugarcane Breed. Inst. Newsl. 18:23.

Viswanathan, R., Chinnaraja, C., Parameswari, B. and Chhabra, M. L. 2016. Status of yellow leaf resistance in sugarcane germplasm and parental clones at Sugarcane Breeding Institute, India. Int. Sugar J. 115:60-71.

Viswanathan, R. and Rao, G. P. 2011. Disease scenario and management of major sugarcane diseases in India. Sugar Tech 13:336-353. 